\title{
A Review of the Literature on the Integration of Technology into the Learning and Teaching of English Language Skills
}

\author{
Abbas Pourhosein Gilakjani ${ }^{1}$ \\ ${ }^{1}$ Lahijan Branch, Islamic Azad University, Lahijan, Iran \\ Correspondence: Abbas Pourhosein Gilakjani, Lahijan Branch, Islamic Azad University, Lahijan, Iran. Tel: \\ 98-13-4263-2762. E-mail: abbas.pourhossein@yahoo.com
}

Received: June 26, 2017 Accepted: July 19, $2017 \quad$ Online Published: July 26, 2017

doi:10.5539/ijel.v7n5p95 URL: http://doi.org/10.5539/ijel.v7n5p95

\begin{abstract}
Technologies have dramatically changed the way people gather information, carry out research, and communicate with others worldwide. Technology has removed the distance obstacles and has made it possible for higher education to effectively teach anyone. Technology integration is being increasingly used in instruction to improve teaching and learning. This rapid development of technology integration has presented a better pattern to find the new teaching models. Consequently, it has a key role in learning and teaching language skills. The integration of technology to create a context to teach and learn English skills has a lot of advantages. The fundamental aim of this paper is to review the issues related to technology integration in the learning and teaching of language skills. In this paper, the researcher defines the term technology integration, expresses the reason of integrating technology, explains the role of technologies in promoting learning, elaborates teachers' roles and learners' roles, reviews previous studies on the benefits of technology in the learning and teaching of language skills, indicates the situation of Information and Communication Technologies (ICTs) in Iran, and finally mentions the recommendations for the successful integration of technology. The review of literature revealed that the integration of technology into the classrooms considerably improves the learning and teaching of English language skills.
\end{abstract}

Keywords: technology integration, learning, teaching, skills, benefits, ICTs, recommendations

\section{Introduction}

The method of English language teaching has been considerably changed due to the entry of technology. Technology offers a lot of benefits as making teaching interesting and more productive in terms of advancements. The use of technology helps learners get involved and learn based on their interests. It has been extensively accepted for teaching English in the modern world. Technology satisfies both visual and auditory senses of the learners (Solanki \& Shyamlee1, 2012). Graddol (1997) said that technology is the center of the globalization process and impacts education and culture.

Friggard (2002), Miner (2004), and Timucin (2006) confirmed that technology increases the development of teaching methods and learners' knowledge. Lam \& Lawrence (2002) also expressed that technology helps learners to regulate their own learning process and have access to many information that their teachers cannot provide. Pourhosein Gilakjani and Lai-Mei (2012) elaborated that the unique opportunities technologies provide have brought about new tools, approaches, and strategies in the teaching and learning of language skills. Technologies are increasingly widespread, impacting many aspects of our social and work lives, and many of our leisure activities.

Many researchers stated that technology can be used as an instructional tool in teaching and learning skills. Pourhosein Gilakjani (2013) and Bruce and Levin (2001) expressed that technology can be useful in classroom by helping communication, making teaching products, and assisting learners' self-expression. According to Pourhosein Gilakjani (2013), when we talk about instruction, education, or training issues we have to consider the important role of technology. The researchers continued that the application of technologies in education opens a new area of knowledge and provides a tool that has the great potential to change the existing teaching methods.

The effect of using technology on education has been examined by different researchers in various fields. All of these researchers unanimously agreed that technology helps teachers improve their teaching methods and 
learners increase their knowledge (Frigaard, 2002; Pourhosein Gilakjani \& Sabouri, 2014; Schofield \& Davidson, 2003; Timucin, 2006). When using technology, learners not only control their own learning process, but also have access to further information over which their teachers cannot control (Pourhosein Gilakjani \& Sabouri, 2014).

Technology plays a key role in promoting appropriate activities for learners and has a significant impact on teachers' teaching methods in their classes. Technological advancements have gone hand -in-hand with the development of English and are changing the way in which we communicate. If we ignore technological developments in our classes we will never be able to keep up with these technologies. Therefore, it is very important for teachers to be aware of the latest equipment and to have a full knowledge of these technologies in different situations. There are different reasons why all learners and teachers should know how to use the new technologies. It should be mentioned that the new technologies develop and disseminate and we cannot ignore their impact on teaching and learning (Solanki \& Shyamlee1, 2012).

In this review article, the researcher will examine some of the important issues related to the integration of technology in learning and teaching language skills. These issues are as follows: the definition of technology integration, the reason of integrating technology, the role of technologies in promoting learning, teachers' roles, learners' roles, previous studies on the benefits of technology integration in the learning and teaching of language skills, the situation of Information and Communication Technologies (ICTs) in Iran, and the recommendations for the successful integration of technology.

\section{Definition of Technology Integration}

There are different views towards the definition of technology integration. According to Cuban, Kirkpatrick, and Peck (2001) and Hew and Brush (2007), technology integration is defined in terms of kinds of teachers' computer use into the classes: low-level (e.g., learners performing Internet searches) or high-level use (e.g., learners performing multimedia presentations, collecting, and interpreting data for projects). Hennessy, Ruthven, and Brindley (2005) defined technology integration in terms of how teachers utilize technology to do familiar tasks more productively and how this utilization can re-shape these tasks.

According to Lim et al. (2003) and Hew and Brush (2007), technology integration is defined in terms of teachers applying technology to develop learners' thinking skills. Technology integration is the utilization of technology tools in general content areas in education in order to permit learners to use computer and technology skills to learning and problem-solving. Technology integration is defined as the application of technology to improve the educational environment. Technology integration in the classroom can support classroom instruction through creating opportunities for learners to complete assignments on the computer rather than the normal pencil and paper (Dockstader, 2008).

\section{Integration of Technology into the Classroom}

According to Dockstader (2008), there are some important reasons for integrating technology into the classes. They are as follows:

1) Through integrating technology, more depth into the content-area syllabus would be possible.

2) In the information age, there is an urgent need to learn technology.

3) Learners are motivated through technology that ultimately enhances academic engagement time.

4) Working in more depth with the content, learners can move beyond knowledge and comprehension to application and analysis of information.

5) Learners learn where to find information in an information rich world.

6) Computer skills should not be taught in isolation.

7) Learners develop computer literacy through using different computer skills as part of the learning process.

According to Billings and Mathison (2011), there are two reasons that educational technologies assist in raising learners' achievement. The first reason is that they perform a very good job of engaging the learners in the material. The second one is that they get learners excited to take part in the educational tasks. One of the basic advantages of integrating technology into the classes is that when they are applied suitably they can make learning more fun for the learners. If the learners have a lot of enjoyable materials they will be engaged in the lesson that will help them better understand the learning materials. Furthermore, when the lessons are fun for the learners they will be more excited to take part. In order for teachers to integrate technology effectively, they should know how to appropriately use them and how to teach their learners to use them accurately. According to Oliver, Osa, and 
Walker (2012), technology integration helps learners become capable information technology users, information seekers, analyzers, evaluators, problem solvers, decision makers, creative users of technology tools, communicators, and collaborators.

\section{How Technologies Promote Learning}

According to Jonassen, Howland, Marra, and Crismond (2008), if technologies are used to promote meaningful learning, they should be used as facilitators of thinking. The following roles have been suggested for technologies in supporting meaningful learning:

1) Technology is a tool that supports knowledge construction for indicating learners' opinions, understandings, and beliefs and producing organized knowledge bases by learners.

2) Technology is an information vehicle for finding knowledge to support learning by making for accessing the necessary information and comparing beliefs and worldviews.

3) Technology is a real context to support learning by doing for showing and arousing meaningful difficulties, situations, and contexts, revealing beliefs, views, arguments, and defining a controllable problem space for students' thinking.

4) Technology is a social means to support learning by talking for cooperating with others, discussing, reasoning, and reaching an agreement among members of a society, and supporting conversation among knowledge-based communities.

5) Technology is an intellectual partner to support learning by thinking for helping learners to express and indicate what they know, thinking about what they have learned and how they came to know it, supporting learners' internal discussions and meaning constructing, making personal representations of meaning, and supporting creative thinking.

Technology has a positive effect on learners' learning. It causes learners to be more engaged; therefore, they can keep more information. Technology provides meaningful learning experiences. It gives learners more opportunities to cooperate with their peers leading to learning from each other (Costley, 2014). According to Costley (2014) and DePasquale, McNamara, and Murphy (2003), technology is a powerful contributor to learning if it is used to deepen learners' engagement in meaningful and authentic curriculum. Technology is a learning tool. It should be chosen when it is the best tool for learners to learn. Technology can be an effective tool for language learners. Learners should start using technology tools as an important part of their academic program. Teachers should model the application of technology in support of the curriculum so that learners can see the correct use of technology and benefit from exposure to more advanced applications that they will use independently in the future.

Kurt (2010) stated that technology can be used as a tool for performing meaningful projects to engage learners in critical thinking and problem solving. Technology can be used to restructure the language classes to produce an environment that promotes the growth of thinking skills. Technology increases learners' cooperation. Cooperation is an effective tool for learning. Learners cooperatively work together to create projects and learn from each other through reading their peers' work (Keser, Huseyin, \& Ozdamli, 2011).

\section{Teachers' Roles}

Teachers are the main agents of integrating technology in the classrooms. If we do not consider their role in implementing technology, it will bring about just limited effects for the learning process (Ferguson, 1997). Wenglinsky (2001) stated that technology itself does not make a significant effect on learners' achievement without paying attention to the teachers' role in its integration.

According to Fishman and Davis (2006) and Zhu (2010), teachers are considered as an important factor in educational technologies. Technologies are increasing basic changes in the teachers' role and in the classroom activities. Zhu (2010) said that teachers have different roles. They are called expert, formal authority, personal model, facilitator, and delegator. In the role of expert, the teachers should have a lot of knowledge about the area they teach and should play the role of knowledge source for their learners.

In the role of authority, the teachers should be very knowledgeable about the subject they teach and they consider themselves to be authoritarian in this area and learners should follow the rules the teachers determine for them. In the role of model, what the teachers say, perform or indicate in the classes acts as a model for learners to follow and learn from their teachers and this role can have an important effect on their learners' development (Zhu, 2010).

In the role of facilitator, the teachers guide their learners to learn new things according to what they already know and facilitate their learning processes. In the delegator role, the teachers give assignments to learners and urge 
them to work independently. According to Zhu, Valcke, and Schellens (2010), the adoption of particular teacher roles in the use of technologies can facilitate or stop learners' ability to acquire language skills. It should be mentioned that teachers can adopt the above roles in different situations.

Kook (1997) stated that technologies change the teaching and learning process and the roles of the teachers will certainly change. Teachers will have the roles of information consultants, team collaborators, facilitators, course developers, and academic advisors. Cuban (1986) indicated that teachers are the gatekeepers of instructional technology. Teachers have a significant role in performing changes into their classes and providing the bridge between the school's objectives and the advantages learners get from these objectives.

Teachers are the key persons in using ICT in schools because they are at the center of changing and can change the teaching and learning process; thus, the implementation of ICT depends on their eagerness and skills (Mooij \& Smeets, 2001). Albirini (2006) emphasized that teachers who have positive beliefs in the cultural aspects of computer technology will use it in education. Williams et al. (2000) expressed that teachers should be skilled to implement ICT in teaching and learning effectively. According to Tong and Trinidad (2005), some teachers accept the application of computers in their classes but they do not know how to change their teaching methods.

\section{Learners' Roles}

Learners' roles are changed with the integration of technology into their classes. Smith \& Kolosick (1996) and Ozerol (2009) stated that learners' roles change from passive to active with the integration of technology. Classes change from teacher-centered to learner-centered. Teacher-centered classes are traditional ones and learners have passive roles. In these classes, learners just receive information whereas teachers have active organizer roles. Teachers design lessons, identify the objectives of the lessons, and give feedback to their learners. Through changing teacher-centered classes to learner-centered ones, teachers' and learners' roles change. Learners are active participants in the lessons (Ozerol, 2009; Weasenfort \& Meloni, 2002).

In the CALL classes, learners will have the autonomous roles. Jones (2001) and Ozerol (2009) supported this and revealed that CALL leads to autonomy. CALL permits learners to study individually and leads to the learners' autonomy (Pennington, 1996). Learners take the responsibility of their own learning (Madrid, 2005; Ozerol, 2009; Shetzer \& Warshauer, 2000), and do not depend on their teachers through integrating technology in their classes (Jones, 2001). Furthermore, technology permits learners to learn based on their own styles and learners have more freedom in their learning (Volman, 2005) and experience authentic language learning (Wilson \& Thayalan, 2007).

When learners use technology they are not only recipients of information they have also active role in learning and teaching. They select, receive information and then transfer and use them. Technologies permit learners to identify their interests and capabilities. According to the learning pace, learners get update information and knowledge and communicate with their society (Zamani Farahani, Bahamiriyan, \& Sadeghi, 2015). ICT enables learners to learn according to their own pace and level and they can control their learning, urges active learning rather than passive, promotes physical and mental abilities of learners, and involves learners in study and data analysis, so facilitates higher-levels of thinking process (Zamani Farahani, Bahamiriyan, \& Sadeghi, 2015).

\section{Previous Studies on the Benefits of Technology Integration}

The benefits of technology integration in language learning have been reported in numerous studies. These studies involve various aspects of language learning and are discussed in the following section. One of the benefits of integrating technology is the increase of learners' motivation (Dunken 1990; Riasati, Allahyar, \& Tan, 2012). This is an important factor that can bring about a lot of benefits for learners in their language classes (Galavis 1998; Riasati, Allahyar, \& Tan, 2012; Warschauer \& Healey, 1998). The use of technology can improve learners' academic ability. According to Lee (2001), the use of Computer Assisted Language Learning (CALL) changed learners' learning attitudes and increased their self-confidence. This has been supported by Galavis (1998), Dunken (1990), and Riasati, Allahyar, and Tan (2012) who expressed that the application of technology increases learners' language proficiency and their academic skills.

The integration of technology has changed the methods from teacher-centered to learner-centered ones in language learning and teaching. Teachers should be facilitators and support and guide their learners' learning (DEECD, 2010; Riasati, Allahyar, \& Tan, 2012). This change can be very useful for learners to increase their learning. The other advantage of using technology is the increase of cooperation in learning activities. Gillespie (2006) said that technology helps learners gather information and interact with resources like images and videos. Murphy (2006) expressed that technology enables the users to get connected to the world and produce high-quality work.

The use of technology can lower learners' anxiety (Chapelle, 2001; Riasati, Allahyar, \& Tan, 2012). A study was 
done by Ozerol (2009) and the results showed that technology lowered learners' learning anxiety and gave them more opportunity to communicate. This finding is in line with Braul's (2006) study, indicating that the use of computers in the classes developed learners' learning skills and enhanced their autonomy. In language classes, teachers' role should be changed from "sage on the stage" to "guider on the side," while learners should actively explore responses instead of receiving them. The use of technology helps this changing process for teachers and learners (Anderson \& Speck, 2001).

Nowadays the significance of technology integration in educational field is well known. Technology helps the learners and the teachers in studying the course materials easily due to the fast access. The use of technology in the syllabus in schools, colleges, and universities has helped them in understanding the subjects well and getting their basics cleared. Improvements in technology play a significant role in preparing learners to use what they learn in any subject to finding their place in a global labor-force. Technology facilitates learners' learning and serves as the real educational structure permitting learning to happen (Rodinadze \& Zarbazoia, 2012).

The integration of technology helps teachers choose their own favorite multimedia and software that creates more interactive lessons. The traditional lecture-based lessons do not stimulate learners. By including technology in their classes, teachers will have the opportunity to engage more learners and lead more energetic classes. Multimedia presentation software allows both teachers and learners to organize, present, and use information in new ways. For instance, in the English classes different presentations may be made based on the subjects through using computer and overhead projector. Moreover, multimedia software allows teachers to design audio-visual narrative themes including the learner's actual participation (Rodinadze \& Zarbazoia, 2012).

Through using technology, teachers can increase literacy and understanding in any subject. Lessons with audio and video components motivate more learners to participate in class and raise their understanding. Students can pass exams through computers. Besides they may check their progress (scores) through internet. The Use of technology in education can be a great benefit for teachers. Teachers now have the ability to work together to create more meaningful instruction for all learners without having to arrange planning time. Teachers can use websites to assign requirements and samples for learners (Rodinadze \& Zarbazoia, 2012).

Hennessy (2005) found that ICTs can motivate teachers and learners to work in peer discussion, exploration, analysis and thinking, examining, and assistance. The researcher understood that as learners become more independent, teachers should encourage and support their learners in acting and thinking independently. According to Warschauer (2000) and Parvin and Salam (2015), through using technology into the classes, learners can get the opportunity to increase their exposure to language in a meaningful context and make their own individual knowledge. Learners should be also given opportunities for true social interactions to practice real life skills. This can be obtained through learners' cooperation on real activities and projects.

One study was done about the effect of Wiki technology on improving learners' writing skills. Learners were asked to join a Wiki page where they would write passages and read and respond to the passages of their fellow classmates. The results of this study indicated that receiving immediate feedback from the instructor was very useful for learners while using this form of technology. Learning vocabulary, spelling, and sentence structure through reading the work of their classmates were the other benefits of using this technology for learners (Costley, 2014; Lin \& Yang, 2011).

Bulut and Delen (2011) and Costely (2014) investigated the impacts of information and communication technologies on learners' math and science attainment. The findings of this research revealed that learners' exposure to Information and communication technology at home and school had a significant effect on their math and science attainment scores. Learners' who used technology more increased their science knowledge. These learners had better performance on their math skills. It was concluded that information and communication technology has a great impact on learners' learning and should be incorporated in language teaching. The other study was carried out by Baytak, Tarman, and Ayas (2011) towards the impact of using technology on learning. The results showed that the learners' learning was improved by incorporating technology into their classes. Technology made learners' learning interesting, enjoyable, and interactive. The use of technology increased learners' motivation, their social interactions, learning, and engagement.

Mohamadkhani, Nazari Farokhi, and Nazari Farokhi (2013) demonstrated that the use of new technologies has a great effect on listening comprehension. Wagner (2006) expressed that the use of visual means permits listeners to make more valid inferences and this will in turn lead to the improvement of listening performance. Field (2008) also had the same opinion and stated that our perception of the conversation can be affected by visual cues. Some studies have been done concerning the effect of technology on improving listening comprehension (Diao, Chandler, \& Sweller, 2007; Jones \& Plass, 2002; Mohamadkhani, Nazari Farokhi, \& Nazari Farokhi, 
2013). The results indicated that learners' learning with double mode (sound and text) outperformed learners' learning with single mode (sound).

Volle (2005 as cited in Baniabdelrahman, 2013) examined the learning of oral skills in an online course for Spanish learners. Learners were asked to utilize audio e-mails to record two speaking activities-one before the beginning of the course and the other at the end. These were compared to get a better picture of the improvement in learners' oral performance. The results of this study showed that learners considerably improved their oral proficiency.

Barr, Leaky, and Ranchoux (2005) performed a study to provide French learners with cooperative and individual learning by a digital medium in their face-to-face conversation classes. The results obtained from this research represented that by the end of the study, the control group indicated greater advancement in oral proficiency than the experimental group. Maggie and Deniz (2011) investigated the impact of podcasts on the Spanish speaking skills. After six months, the research indicated that the frequency and variety of designed weekly podcasting assignments helped learners improve their speaking skills.

\section{The Situation of Information and Communication Technologies in Iran}

According to Zare-ee (2011), one of the most effective changes in higher education is the utilization of Information and Communication Technologies (ICTs). Modern ICTs in higher education has a short history but spreading with high speed in various contexts. ICTs is the all forms of communication technologies such as computers, videos, hardware, networks, and software that can be used for educational and research objectives. There are some uncertainties toward using ICTs in Iranian higher education. The application of ICTs is accompanied by the feelings of hope and despair. The history of the use of ICTs in Iran is shorter than the general history of the use of modern technologies in education all over the world.

Zare-ee (2011) continued that although there have been uncertain feelings of hopelessness and helplessness toward using ICTs in Iran, institutions of higher education have tried to pave the way for using ICTs in their learning and teaching activities. These institutions include public universities, private universities called Azad University branches, and distant learning centres called Payame-Noor University branches. All universities have websites that are equipped with an ICT center where Information Technology (IT) assistance is provided. The researcher said that in all public universities, institutional email addresses are provided for all learners and teachers. In these universities, most dormitories are equipped with small computers and Internet centers where learners can use them and connect to their low-speed Internet. All staff rooms in public universities and most staff offices in Azad and Payame-Noor universities have a personal computer connected to the Internet. Student registration and student record tracking are done by the Internet in some cities of the country and some students have to go to the nearby internet cafes for their services.

Presently, many learners enter the university with anticipations that ICTs will be accessible, available, and efficiently utilized. In Iran, many learners are not aware of current developments in ICTs or are digitally less educated to have the similar anticipations. The advantages of ICTs in higher education cannot be restricted to teaching and learning. Teachers and learners in institutions of higher education can do a lot of researches through using ICTs because they are very useful resources. Tools such as emails, blogs, databases, analysis software, and many other forms of ICTs can be used in all stages of the research process such as selecting the research topic, collecting the data, doing data analysis, summarizing findings, and drawing implications for the discussion of results. Consequently, ICTs can assist the Iranian EFL university teachers in both instruction and research (Zare-ee, 2011).

There are not enough researches concerning the Iranian EFL university teachers' opinions toward the usefulness of ICTs in higher education. There are different and contradictory results of the studies done regarding the utilization of ICTs for university teaching and learning. A study was done by Sarmadi, Ebrahimzadeh, Tafazoli Moghadam, and Dayani (2010) about the factors influencing the use of ICTs for research and instruction among Iranian faculty members. The researchers found major impacts on the ICT use for perceived complexity of ICT, positive attitudes towards the benefits of ICTs, perceived testability of teaching and learning through ICT, and skill in English as a foreign language. According to Sharifi (2003), the Iranian EFL university teachers have reported significant effects on the use of ICT for the fields of study, age, university degree, and teaching experience. It has been reported that university teachers in the humanities and older teachers use ICTs less than all others. Salajagheh (2010) investigated the users' attitudes toward computers in Shiraz University in Iran. Findings indicated that the users had positive attitudes toward ICT in teaching and learning of language skills.

Montazeri, Vakili, and Seyyed Ebrahimi (1385 as cited in Ghaznavi, Keikha, \& Yaghoubi, 2011) carried out a study on the impact of information technology on education in Tehran. The results indicated that the use of information technology in education was regarded as a facilitation factor that improved the quality of education. It 
also changed the concepts of traditional teaching methods. It was concluded that the use of information technology has a great effect on the evaluation of teaching methods, the value of learning, and the relationship between teacher and learner. Islami (1387 as cited in Ghaznavi, Keikha, \& Yaghoubi, 2011) performed a study toward the development of ICT in Mazandaran province and concluded that schools do not have sufficient computer equipment, LCDL skill position is not in a desired level, and teachers have high motivation to use information and communication technology in teaching language skills.

\section{Recommendations for the Successful Integration of Technology}

In this section, some recommendations have been offered for teachers to improve their skills in the appropriate integration of technology in their classes (Burniske \& Monke, 2001; Dexter \& Anderson, 2002; Fishman \& Pinkard, 2001; Keengwe \& Onchwari, 2009; Lim \& Khine, 2006; Rogers, 2000).

1). University authorities should consider technology necessity as an important part of the teaching and learning programs.

2). While teachers consider the important role of time for the preparation of their lessons, technology professional development tasks should be aligned to their lessons.

3). University authorities should install new technology tools that support new instructional software.

4). Technology integration experts should follow-up with teachers who attend professional development programs to provide extra assistance when needed.

5). Technology technicians should assist teachers in their possible questions such as attending their classes to help them develop their lessons and indicate them the appropriate utilization of a specific program.

6). Teachers should create technology-integrated lesson plans and materials. These plans and materials should center on teaching and learning, not merely on technology issues.

7). Teachers should not realize that the adoption of technology is a panacea. They should try to find the appropriate place and time for the teaching reasons of its application.

8). Teachers should try to find the ways that technology can help them accelerate teaching reform toward more learner-centered and constructivist learning as opposed to traditional methods of teacher-centered and one-way instruction.

9). Teachers should be provided with technical assistance. . In order to facilitate the integration of technology, adequate support and technical assistance should be provided for teachers. It means that the necessary training periods should be offered to teachers.

10). Teachers should search for training opportunities to learn how to use and teach technology effectively and easily.

11). Teachers should know that their need to learn new skills means learning from others, their own students, professional trainers, or other teachers. Patience is needed for teachers to learn new techniques, to use them in their classes, and to accept comments/suggestions from others.

12). Students' access to computers does not mean that teachers do not have any roles in guiding them. On the contrary, it requires teachers to project into their learners' learning, showing that learners reflect on their learning, develop information-reasoning skills, and help them to get a deeper understanding of the subject matter.

13). Teachers should also seek the guidance from their colleagues who are advanced technology integrators who can help them teach better through integrating technology.

\section{Conclusion}

Studies reviewed here indicated that technology offers both teachers and learners a lot of materials and communication opportunities to improve their language teaching and learning. In order to successfully integrate technology in language classes, both teachers and learners should adopt new roles and use the existing technologies in suitable ways. It is obviously true that one of the ultimate aims of technology language learning and teaching is to promote learners' motivation and learning interest which can be a practical way to get them involved in the language learning process. The literature displayed that teachers should be prepared with professional skills which involve teaching and technical skills because if teachers are more knowledgeable, they will be able to successfully implement technologies in their language classes. This review paper revealed that learners can benefit from the technology-based activities provided that they are related to their needs and interests. The findings of this review paper represented that technology integration allows teachers to be more creative and more effective in their teaching and it motivates learners to be engaged in classroom activities. The literature 
review indicated that technology integration helps learners learn what they want to learn and learn more than what teachers ask them to learn. It is because of technology integration that more and more learners and teachers are becoming more interested in learning and teaching foreign language skills. It is expected that technology integration will continue its contribution to the effective learning and teaching of English language skills. Furthermore, teachers should always remember that technology is just a tool, and learners' learning progress depends on the suitable and creative instruction. In addition, through technology-based English teaching, learners will be more motivated and guided to communicate with each other and the process of learning skills will be more student-centered but less time-consuming. The findings of the studies of this paper can be beneficial for both teachers and learners. While experienced teachers know how to teach English language skills through integrating technology, many teachers should have training courses in how to teach the four skills successfully so that their learners make the most of the technology. Finally, teachers should understand the benefits that technology integration brings to their instruction and their learners' learning.

\section{References}

Albirini, A. (2006). Cultural perceptions: The missing element in the implementation of ICT in developing countries. International Journal of Education and Development using ICT [Online], 2(1). Retrieved from http://ijedict.dec.uwi.edu/viewarticle.php?id=146

Anderson, R., \& Speck, B. (2001). Using technology in K-8 literacy classrooms. Upper Saddle River, N.J.: Prentice-Hall.

Baniabdelrahman, A. A. (2013). Effect of using Internet tools on enhancing EFL students' speaking skill. American International Journal of Contemporary Research, 3(6), 79-87. Retrieved from http://www.iier.org.au/iier20/mansfield.pdf

Barr, D., Leakey, J., \& Ranchoux, A. (2005). Told like it is! An evaluation of an integrated oral development pilot project. Language Learning \& Technology, 9(3), 55-78. Retrieved from http://llt.msu.edu/vol9num3/barr/

Baytak, A., Tarman, B., \& Ayas, C. (2011). Experiencing technology integration in education: children's perceptions. International Electronic Journal of Elementary Education, 3(2), 139-151.

Billings, E., \& Mathison, C. (2011). I get to use an iPod in school? Using technology-based advance organizers to support the academic success of English Learners. Journal of Science Education Technology, 21(4), 494-503. https://doi.org/10.1007/s10956-011-9341-0

Braul, B. (2006). ESL teacher perceptions and attitudes toward using computer-assisted language learning (CALL): Recommendations for effective CALL practice. MA Dissertation, Department of Secondary Education, Edmonton, Alberta.

Bruce, B., \& Levin, J. (2001). Roles for new technologies in language arts: Inquiry, communication, construction, and expression. In J. Jenson, J. Flood, D. Lapp, \& J. Squire (Eds.), The handbook for research on teaching the language arts. NY: Macmillan.

Bulut, O., \& Delen, E. (2011). The relationship between students' exposure to technology and their achievement in science and math. The Turkish Online Journal of Educational Technology, 10(3), 311-317.

Burniske, R. W., \& Monke, L. (2001). Breaking down the digital walls: Learning to teach in a post-modem world. Albany, NY: SUNY Press.

Chapelle, C. A. (2001). Computer applications in second language acquisition foundations for teaching, testing, and research. Cambridge University Press, UK. https://doi.org/10.1017/CBO9781139524681

Costley, K. C. (2014). The positive effects of technology on teaching and student learning. Arkansas Tech University.

Cuban, L. (2001). Oversold and underused: Computers in the classroom. Cambridge, MA: Harvard University Press.

Cuban, L., Kirkpatrick, H., \& Peck, C. (2001). High access and low use of technologies in high school classrooms: Explaining an apparent paradox. American Educational Research Journal, 38(4), 813-834. https://doi.org/10.3102/00028312038004813

Department of Education and Early Childhood Development. (2010). Teaching and learning with Web 2.0 technologies. State of Victoria. Retrieved http://www.education.vic.gov.au/edulibrary/public/teachlearn/innovation/technology/web2report.pd 
DePasquale, R., McNamara, E., \& Murphy, K. (2003). Meaningful connections: Using technology in primary classrooms. Young Children on the Web. Retrieved from http://journal.naeyc.org/btj/200311/techinprimaryclassrooms.pdf

Dexter, S., \& Anderson, R. E. (2002). USA: A model of implementation effectiveness. Retrieved from http://edtechcases.info/papers/multicase_implementation.htm

Diao, Y., Chandler, P., \& Sweller, J. (2007). The effect of written text on comprehension of spoken English as a foreign language. American Journal of Psychology, 120(2), 237-261. https://doi.org/10.2307/20445397

Dockstader, J. (2008). Teachers of the 21st century know the what, why, and how of technology integration. Retrieved from http://the-tech.mit.edu/Chemicool/

Dunkel, P. (1990). Implications of the CAI effectiveness research for limited English proficient learners. Computers in the Schools, 7(1/2), 31-52. http://dx.doi.org/10.1300/J025v07n01_02

Ferguson, B. (1997). Educational technology: An extended literature review. Retrieved from http://www.sdavjr.davis.k12.ut.us/ brian/research/exlitrev.htm

Field, J. (2008). Listening in the language classroom. Cambridge: Cambridge University Press.

Fishman, B., \& Davis, E. (2006). Teacher learning research and the learning sciences. In R. K. Sawyer (Ed.), The Cambridge handbook of the learning sciences (pp. 535-550). Cambridge: Cambridge University Press.

Frigaard, A. (2002). Does the computer lab improve student performance on vocabulary, grammar, and listening comprehension? ERIC Document Reproduction Service No. ED476749.

Galavis, B. (1998). Computers and the EFL class: Their advantages and a possible outcome, the autonomous learner. English Teaching Forum, 36(4), 27. Retrieved from http://exchanges.state.gov/forum/vols/vol36/no4/index.htm

Ghaznavi, M. R., Keikha, A., \& Yaghoubi, N. M. (2011). The impact of information and communication technology (ICT) on educational improvement. International Education Studies, 4(2), 116-125. https://doi.org/10.5539/ies.v4n2p116

Gillespie, H. (2006). Unlocking learning and teaching with ICT: Identifying and overcoming barriers. London: David Fulton.

Graddol, D. (1997). The future of English? A guide to forecasting the popularity of the English language in the 21st century (Vol. 29). The British Council. Retrieved from https://doanbangoc.files.wordpress.com/2012/07/the-future-of-english.pdf

Hennessy, S. (2005). Emerging teacher strategies for supporting. Cambridge, UK: University of Cambridge.

Hennessy, S., Ruthven, K., \& Brindley, S. (2005). Teacher perspectives on integrating ICT into subject teaching: Commitment, constraints, caution, and change. Journal of Curriculum Studies, 37(2), 155-192. http://dx.doi.org/10.1080/0022027032000276961

Hew, K. H., \& Brush, T. (2007). Integrating technology into K-12 teaching and learning: current knowledge gaps and recommendations for future research. Education Tech Research Dev, 55, 223-252. https://doi.org/10.1007/s11423-006-9022-5

Jonassen, D., Howland, J., Marra, R. M., \& Crismond, D. (2008). How does technology facilitate learning? Meaningful Learning with Technology (5-10). NJ: Pearson Allyn Bacon Prentice Hall.

Jones, J. (2001). CALL and the teacher's role in promoting learner autonomy. CALL-EJ Online, 3(1). Retrieved from http://www.tell.is.ritsumei.ac.jp/callejonline/journal/3-1/jones.html

Jones, L. C., \& Plass, J. L. (2002). Supporting listening comprehension and vocabulary acquisition in French with multimedia annotations. The Modern Language Journal, 86(4), 546-561. http://dx.doi.org/10.1111/1540-4781.00160

Keengwe, J., \& Onchwari, G. (2009). Technology and early childhood education: A technology integration professional development model for practicing teachers. Early Childhood Educ J, 37, 209-218. https://doi.org/10.1007/s10643-009-0341-0

Keser, H., Uzunboylu, H., \& Ozdamli, F. (2012). The trends in technology supported collaborative learning studies in 21st century. World Journal on Educational Technology, 3(2), 103-119.

Kook, J. (1997). Computers and communication networks in educational settings in the twenty-first century: 
Preparation for educators' new roles. Educational Technology, 37(2), 56-60.

Kurt, S. (2010). Technology use in elementary education in Turkey: A case study. New Horizons in Education, $58(1), 65-76$.

Lam, Y., \& Lawrence, G. (2002). Teacher-student role redefinition during a computer-based second language project: Are computers catalysts for empowering change? Computer Assisted Language Learning, 15(3), 295-315. https://doi.org/10.1076/call.15.3.295.8185

Lim, C. P., \& Khine, M. S. (2006). Managing teachers' barriers to ICT integration in Singapore schools. Journal of Technology and Teacher Education, 14(1), 97-125. Retrieved from http://www.gtce.org.uk/Newsfeatures/features/tlaspeech>

Lim, C. P., Teo, Y. H., Wong, P., Khine, M. S., Chai, C. S., \& Divaharan, S. (2003). Creating a conducive learning environment for the effective integration of ICT: Classroom management issues. Journal of Interactive Learning Research, 14(4), 405-423.

Lin, W., \& Yang, S. (2011). Exploring students' perceptions of integrating Wiki technology and peer feedback into English writing courses. English Teaching: Practice and Critique, 10(2), 88-103.

Madrid, M. N. R. (2005). Learner autonomy in computer-assisted language learning. A comparative case study of learners' behavior in the English as a foreign language context. Ph.D. Dissertation, Universitat Jaume I, Castellon.

Maggie B. J., \& Deniz P. (2011). Podcasting as a means of improving Spanish speaking skills in the foreign language classroom: An action research study. Networks, 13(1), 1-18. Retrieved from http://journals.library.wisc.edu/index.php/networks/article/view/277

Miner, T. (2004). Using technology to enhance learning: Instructor-or student-moderated discussion boards: Which are more effective? Retrieved from $\mathrm{http} / / / \mathrm{www} . c c c o n e . o r g /$ scholars/0405/TomMiner_final_report.pdf

Mohamadkhani, K., Nazari Farokhi, E., \& Nazari Farokhi, H. (2013). The effect of using audio files on improving listening comprehension. International Journal of Learning \& Development, 3(1), 132-137. https://doi.org/10.5296/ijld.v3i1.3187

Mooij, T., \& Smeets, E. (2001). Modelling and supporting ICT implementation in secondary schools. Computers \& Education, 36(3), 265-281. https://doi.org/10.1016/S0360-1315(00)00068-3

Murphy, C. (2006). The impact of ICT on primary science. In P. Warwick, E. Wilson \& M. Winterbottom (Eds.), Teaching and Learning Primary Science with ICT. Berkshire, England: Open University Press.

Oliver, A., Osa, J. O., \& Walker, T. M. (2012). Using instructional technologies to enhance teaching and learning for the 21 st century preK-12 students. International Journal of Instructional Media, 39(4), 283-295.

Ozerol, G. (2009). Perceptions of EFL primary school teachers towards CALL. MA thesis. Institute of Social Sciences, English Language Teaching Department, Cukurova University, Turkey.

Parvin, R. H., \& Salam, S. F. (2015). The effectiveness of using technology in English language classrooms in government primary schools in Bangladesh. FIRE: Forum for International Research in Education, 2(1). Retrieved from http://preserve.lehigh.edu/fire/vol2/iss1/5

Pourhosein Gilakjani, A. (2013). Factors contributing to teachers' use of computer technology in the classroom. Universal Journal of Educational Research, 1(3), 262-267.

Pourhosein Gilakjani, A., \& Lai-Mei, L. (2012). Teachers' attitudes toward using computer technology in English language teaching. Theory and Practice in Language Studies, 2(3), 630-636. https://doi.org/10.4304/tpls.2.3.630-636

Pourhosein Gilakjani, A., \& Sabouri, N. B. (2014). Role of Iranian EFL teachers about using Pronunciation Power Software in the instruction of English pronunciation. English Language Teaching, 7(1), 139-148.

Riasati, M. J., Allahyar, N., \& Tan, K. E. (2012). Technology in language education: Benefits and barriers. Journal of Education and Practice, 3(5), 25-30.

Rodinadze, S., \& Zarbazoia, K. (2012). The advantages of information technology in teaching English language. Frontiers of Language and Teaching, 3, 271-275.

Rogers, P. L. (2000). Barriers to adopting emerging technologies in education. Journal of Educational Computing Research, 22(4), 455-472. https://doi.org/10.2190/4UJE-B6VW-A30N-MCE5 
Salajagheh, H. (2010). The attitudes of computer users. Unpublished M.A. dissertation, Shiraz University, Shiraz, Iran.

Sarmadi, M. R., Ebrahimzadeh, I., Tafazoli moghadam, A. H., \& Dayani, M. H. (2010). Higher education in Iran: The impact of ICT on open and distance education (the case of Iran). Library and Information Science, 12(4), 37-52. Retrieved from http://www.sid.ir/en/index.asp

Schofield, J. W., \& Davidson, A. L. (2003). The impact of internet use on relationship between teachers and students. Mind, Culture, and Activity, 10(1), 62-79. http://dx.doi.org/10.1207/S15327884MCA1001_06

Sharifi, A. (2003). The use of ICT in universities. Unpublished master's thesis, Allameh Tabatabaie University, Tehran, Iran.

Shetzer, H., \& Warschauer, M. (2000). An electronic literacy approach to network-based language teaching. In M. Warschauer \& R. Kern (Eds.), Network-based language teaching: Concepts and practice (pp. 171-185). New York: Cambridge University Press. https://doi.org/10.1017/CBO9781139524735.010

Smith, K. L., \& Kolosick, J. T. (1996). The shift to a learner-centered university: New roles for faculty, students, and technology. Association of small computer users in education (ASCUE) summer conference proceedings, pp. 146-157. North Myrtle Beach, ERIC: ED405829.

Solanki, D., \& Shyamlee1, M. P. (2012). Use of technology in English language teaching and learning: An analysis. 2012International Conference on Language, Medias and Culture IPEDR vol. 33(2012)(2012)IACSIT Press, Singapore. 150-156.

Timucin, M. (2006). Implementing CALL in the EFL context. ELT Journal, 60(3), 262-271. https://doi.org/10.1093/elt/ccl006

Tong, K. P., \& Triniada, S. G. (2005). Conditions and constraints of sustainable innovative pedagogical practices using technology. Journal of International Electronic for Leadership in Learning, 9(3), 1-27.

Volman, M. (2005). A variety of roles for a new type of teacher educational technology and the teaching profession. Teaching and Teacher Education, 21(1), 15-31. https://doi.org/10.1016/j.tate.2004.11.003

Wagner, M. (2006). Utilizing the visual channel: An investigation of the use of video texts on tests of second language listening ability. Unpublished doctoral dissertation. Teachers College, Columbia University, New York.

Warschauer, M., \& Healey, D. (1998). Computers and language learning: An overview. Language Teaching, 31(1), 57-71. https://doi.org/10.1017/S0261444800012970

Warschauer, M., \& Meskill, C. (2000). Technology and second language learning. In J. Rosenthal (Ed.), Handbook of undergraduate second language education (pp. 303-318). Mahwah, New Jersey: Lawrence Erlbaum.

Weasenfort, D., Lucas S. B., \& Meloni, C. (2002). Realizing constructivist objectives through collaborative technologies: Threaded discussions. Language Learning \& Technology, 6(3), 58-86.

Wenglinsky, H. (2001). Flunking ETS: How teaching matters. Education Matters, 1(2), 75-78. Princeton, NJ: Policy Information Centre.

Williams, D., Coles, L., Wilson, K., Richardson, A., \& Tuson, J. (2000). Teachers and ICT: current use and future needs. British Journal of Educational Technology, 31(4), 307-320. https://doi.org/10.1111/1467-8535.00164

Wilson, D., \& Thayalan, V. (2007). The role and relevance of CALL. Karen's Linguistics Issues. Retrieved from http://www3.telus.netlinguisticsissuesrolecall.html

Zamani Farahani, P., Bahamiriyan, M., \& Sadeghi, M. (2015). Information and communication technology in education of Iran. Int. J. Econ. Manag. Soc. Sci., 4(1), 100-104.

Zare-ee, A. (2011). University teachers' views on the use of information and communication technologies in teaching and research. The Turkish Online Journal of Educational Technology, 10(3), 318-327.

Zhu, C. (2010). Teacher roles and adoption of educational technology in the Chinese context. Journal for Educational Research Online, 2(2), 72-86.

Zhu, C., Valcke, M., \& Schellens, T. (2010). A cross-cultural study of teacher perspectives on teacher roles and adoption of online collaborative learning in higher education. European Journal of Teacher Education, 33(2), 147-165. http://dx.doi.org/10.1080/02619761003631849 


\section{Copyrights}

Copyright for this article is retained by the author(s), with first publication rights granted to the journal.

This is an open-access article distributed under the terms and conditions of the Creative Commons Attribution license (http://creativecommons.org/licenses/by/4.0/). 